\title{
Spectrophotometric Determination of Bismuth(III) with Arsenazo(III) Reagent in Water samples and Veterinary Preparation
}

\author{
Salim A. Mohammad*
}

\author{
Mohammed M. Mohammed*
}

Received 1, October, 2012

Accepted 6, November, 2012

\begin{abstract}
:
A simple, sensitive and accurate spectrophotometric method for the trace determination of bismuth (III) has been developed.This method is based on the reaction of bismuth (III) with arsenazo(III) in acid solution $(\mathrm{pH}=1.9)$ to form a blue water soluble complex which exhibits maximum absorption at $612 \mathrm{~nm}$.Beer's law is obeyed over the concentration range of 2-85 $\mu$ g bismuth (III) in a final volume of 20 $\mathrm{mL}\left(\right.$ i.e. $\left.0.1-4.25 \mu \mathrm{g} \cdot \mathrm{mL}^{-1}\right)$ with a correlation coefficient of $(0.9981)$ and molar absorptivity $1.9 \times 10^{4} \mathrm{~L} \cdot \mathrm{mol}^{-1} \cdot \mathrm{cm}^{-1}$. The limit of detection (LOD) and the limit of quantification (LOQ) are 0.0633 and $0.0847 \mu \mathrm{g} . \mathrm{mL}^{-1}$, respectively . Under optimum conditions, the stoichiometry of the reaction between bismuth (III) and arsenazo(III) reagent was found to be 1:2. The recoveries were obtained in the range of 98.9 $100.0 \%$ and a relative standard deviation of \pm 0.59 to $\pm 2.73 \%$ depending on the concentration level of bismuth. The effect of interferences by a number of common cations and anions in the presence of composite mixture has been studied.The proposed method has been applied successfully for determination of bismuth in water samples and veterinary preparation .
\end{abstract}

Keywords: bismuth(III), ArsenazoIII, spectrophotometry •

\section{Introduction:}

disorders especially for colitis, diarrhea and peptic ulcers. They were and still are used for burn bandage dressings ,antiseptic powders, and in the treatment of venereal diseases [4,5] . Bismuth forms low-melting alloys which are extensively used for safety devices in fire detection and extinguishing systems [6] . Bismuth is the least toxic among the heavy metals[1]. A number of toxic effects in humans have been attributed to bismuth compounds, such as nephrotoxic, neurotoxic, kidney damage symptoms nephropathy, osteoarthrapathy, hepatitis and neuropathology.
Bismuth is a strategic element, thus its identification and determination are very important [1]. It is found in the earth crust up to $0.0002 \%$ and it is widely found in the form of oxides , carbonates and sulfides in nature .Bismuth is usually obtained as subproduct in lead, copper, tin and gold ores [1,2].During the industrial metalurgical process of these ores, leaching stages with $\mathrm{H}_{2} \mathrm{SO}_{4}, \mathrm{HCl}$, and $\mathrm{HNO}_{3}$ are involved, and highly acidic solutions with base metals and bismuth were obtained [3] Bismuth and its compounds are used in semiconductors , cosmic preparations, medicine for the treatment of syphilis and gastric

\footnotetext{
*Department of Chemistry College of Science Mosul University
} 
AZIII as a chelating agent for determination of bismuth(III) in water samples and veterinary preparation.

\section{Materails and Methods:}

\section{Apparatus}

All absorption spectra and absorbance measurements were carried out by a Shimadzu UV-160 double beam UV-visible spectrophotometer (Japan) with matched $1 \mathrm{~cm}$ quartz cells. While all $\mathrm{pH}$ meas-urements were recorded by using HANNA 211 $\mathrm{pH}$ meter .

\section{Reagents}

All chemicals used are of highest purity available .

Stock bismuth (III) solution (1000 $\mathbf{\text { gg. }} \mathbf{m L}^{\mathbf{- 1}}$ ) : It is prepared by dissolving $0.2312 \mathrm{~g}$ of $\mathrm{Bi}\left(\mathrm{NO}_{3}\right)_{3} .5 \mathrm{H}_{2} \mathrm{O}$ (Fluka) in $3 \mathrm{~mL}$ of $5 \mathrm{M}$ nitric acid and diluted to the mark with distilled water in a $100 \mathrm{~mL}$ volumetric flask [7] .

Working bismuth solution(100 $\mathbf{\mu g .} \mathbf{m L}^{\mathbf{- 1}}$ ) : This solution is prepared by diluting $10 \mathrm{~mL}$ of the stock solution of bismuth to $100 \mathrm{~mL}$ with distilled water in a volumetric flask.

Arsenazo III (AZIII) $\left(\mathbf{5} \times 10^{-4} \mathrm{M}\right)$ : This reagent is prepared by dissolving $0.0388 \mathrm{~g}$ of AZIII (Fluke) in $100 \mathrm{~mL}$ distilled water using a volumetric flask. The solution is then transferred to a brown bottle and remained stable for at least one month .

Nitric acid solution $(0.1 \mathrm{M})$ : It is prepared by diluting $2.25 \mathrm{~mL}$ of concentrated $\mathrm{HNO}_{3}(11.2 \mathrm{M})$ to $100 \mathrm{~mL}$ of distilled water in a volumetric flask .

\section{Composite} mixture solution $(\mathbf{I})(0.01 M) \quad$ : This solution is prepared by dissolving $0.7505 \mathrm{~g}$ of tartaric acid (BDH) with $0.2100 \mathrm{~g}$ of sodium fluoride $(\mathrm{BDH})$ in about 400 $\mathrm{mL}$ distilled water. The $\mathrm{pH}$ of the resulting mixture is adjusted to 1.9 with $0.1 \mathrm{M} \mathrm{HNO}_{3}$ solution and the volume is then completed to $500 \mathrm{~mL}$
As the uses of bismuth in medicine increases, it has spread in the environment and the chance of exposure of organisms to bismuth has increased . Therefore, determination of bismuth in environmental and biological samples is important[7]. Several different techniques have been used for determination of bismuth. These include: hydride generationatomic fluorescence spectrometry (HG-AFS )[8] , Inductively coupled plasma atomic emission spectrometry (ICP-AES)[9], resonance light scattering (RLS)[10] stripping voltammetry[11,17], graphite furnace atomic absorption spectrometry (GFAAS) [5] , square wave voltammetry (SWV) [12] and amperometry [13]. A large number of spectrophotometric methods have been also used for determination of bismuth in various samples due to their simplicity, rapidity, low costs and wide applications, for this purpose widely used reagents were xylenol orange [14] 1,2-diaminocyclohexaneN,N,N,N-tetraacetic

$\operatorname{acid}(\mathrm{DACT})[15], 4-(2-$

benzotholylazo)2,2-biphenyl diol (BTABD)[16], di-(hydrogenated tallow alkyl) dimethylammonium chloride[4] , 1-amino-4,4,6trimethyl $(1 \mathrm{H}, 4 \mathrm{H})$ pyrimidine-2-thiol[1] , bromopyrogallol red in the presence of triton X-114[ 7] , methyl thymol blue [18] , and pyrocatechol violet (PCV)[19] . Some of these methods suffer from several disadvantages, such as, use of heating step, low range of determination , critical working conditions, no applications ,time consuming and poor selectivity. Other methods are typically less sensitive, relatively complicated, or require ion exchange, solvent extraction and expensive instrumentation .These deficiencies have encouraged the authors to develop a simple, selective, sensitive and inexpensive method for the analysis of bismuth. The present work describes the application of 
diluted drug solution is then treated as done in a recommended procedure.

\section{Results and Discussion:}

The preliminary investigation showed that on mixing $50 \mu \mathrm{g} / 20 \mathrm{~mL}$ of bismuth (III) with excess of $5 \times 10^{-4} \mathrm{M}$ AZIII reagent and distilled water in volumetric flask a blue binary water soluble complex [ Bi(III)-AZIII ] was observed and showed a maximum absorption at $613 \mathrm{~nm}$ against the corresponding reagent blank solution . This observation led us to the development of a sensitive method for determination of bismuth based on a binary complex formation. The effect of various parameters on the absorption intensity of the coloured complex was studied and reaction conditions have been optimized .

\section{Effect of pH}

The effect of $\mathrm{pH}$ on the colour intensity of [Bi(III)-AZIII ] complex is investigated by adding different amounts of $0.1 \mathrm{M} \mathrm{HNO}_{3}$ and $0.1 \mathrm{M}$ $\mathrm{NaOH}$ solutions .The complex is showed pH dependent absorption maximum at $612 \mathrm{~nm}$, whereas the reagent blank solution showed maximum absorption at $534 \mathrm{~nm}$. The optimum $\mathrm{pH}$ range for complex formation is 1.9-1.96 ( Fig. 1). $\mathrm{pH} 1.9$ is considered the optimum because of the high absorbance intensity and good colour contrast. with distilled water using a volumetric flask.

Composite mixture solution (II): It is prepared by dissolving $0.8805 \mathrm{~g}$ of ascorbic acid (BDH) in $40 \mathrm{~mL}$ of composite mixture (I) .The $\mathrm{pH}$ of the solution is adjusted to 1.9 with $0.1 \mathrm{M}$ $\mathrm{HNO}_{3}$ and the volume is then completed to the mark with distilled water using a 50 mLvolumetric flask .This solution is freshly prepared .

\section{Recommended procedure}

Aliquots of standard solution (2100) $\mu \mathrm{g}$ of $\mathrm{Bi}(\mathrm{III})$ is transferred into a series of $20 \mathrm{~mL}$ volumetric flasks. To each flask, $3 \mathrm{~mL}$ of $0.1 \mathrm{M}$ nitric acid solution ,2 $\mathrm{mL}$ of composite mixture solution(II) and $1.5 \mathrm{~mL}$ of $5 \times 10^{-4} \mathrm{M}$ AZIII reagent are added .The contents are then completed to the mark with distilled water and mixed well . The absorbance of the formed coloured complexes are measured at $612 \mathrm{~nm}$ against the corresponding reagent blank .

\section{Procedure for dosage form (Veternary sample)}

The content of 3 sachets of Diaclean containing $2000 \mathrm{mg}$ bismuth subnitrate are weighed. A quantity of powder equivalent to $0.01 \mathrm{~g}$ of bismuth is weighed and dissolved in 10 $\mathrm{mL}$ of $2.5 \mathrm{M}$ nitric acid .The solution is then shaken thoroughly, filtered and diluted with distilled water to $100 \mathrm{~mL}$ in a volumetric flask. An aliquot of the

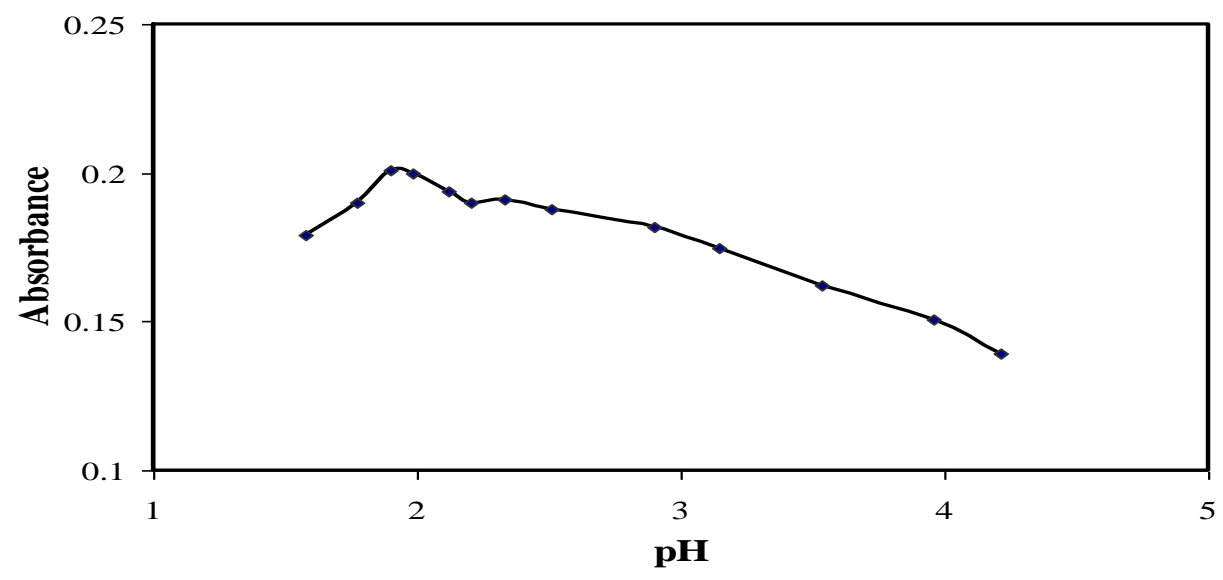


Fig( 1). Effect of apparent pH on absorbance of [Bi(III)-AZIII ] complex of ( 50 $\mu \mathrm{g} / 20 \mathrm{ml} \mathrm{Bi}(\mathrm{III}) ; 1.5 \mathrm{~mL}$ of $5 \times 10^{-4} \mathrm{M}$ AZIII and $0-5 \mathrm{~mL} 0.1 \mathrm{M} \mathrm{HNO}_{3}$ and $0.1 \mathrm{M}$

\section{$\mathrm{NaOH}$ solutions)}

formation of binary complex is investigated .The experimental results indicated that a $1.5 \mathrm{~mL}$ of $5 \times 10^{-4} \mathrm{M}$ AZIII reagent can be considered optimum because of its highest colour sensitivity and lowest corresponding blank value .

\section{Effect of Masking agent on absorbance}

To evaluate the applicability of AZIII reagent to the determination of bismuth, the effect of various masking agents which are usually used for interfering metal ions are studied .The results are shown in table 1.
Different amounts (1-4 mL) of $0.1 \mathrm{M}$ solutions of various acids ( $\mathrm{HNO}_{3}, \mathrm{HCl}, \mathrm{H}_{2} \mathrm{SO}_{4}$ and $\mathrm{HClO}_{4}$ ) have been examined for the purpose of producing intense coloured complex with a strong colour contrast and lower blank value .The results indicate that $\mathrm{HNO}_{3}$ is still the best and gives maximum absorbance and good colour contrast at $\mathrm{pH} 1.9$. Therefore, $3 \mathrm{~mL}$ of $0.1 \mathrm{M} \mathrm{HNO}_{3}$ has been recommended for the subsequent experiments.

\section{Effect of reagent amount}

The influence of different amounts of the AZIII reagent with respect to bismuth(III) on the

Table (1) . Effect of masking agent on absorbance of $50 \mu \mathrm{g} / 20 \mathrm{~mL}$ Bi(III)

\begin{tabular}{|c|c|c|c|c|}
\hline \multirow[t]{2}{*}{ Masking agents* } & \multicolumn{4}{|c|}{ Absorbance/ml. of masking agent } \\
\hline & $\mathbf{0 . 0}$ & 0.5 & 1.0 & 2.0 \\
\hline Ascorbic acid (0.1M) & \multirow{7}{*}{0.267} & 0.268 & 0.264 & 0.262 \\
\hline Tartaric acid $(0.01 \mathrm{M})$ & & 0.269 & 0.265 & 0.271 \\
\hline Succinic acid $(0.01 \mathrm{M})$ & & 0.251 & 0.232 & 0.206 \\
\hline Sulphosalisylic acid $(0.01 \mathrm{M})$ & & 0.248 & 0.233 & 0.220 \\
\hline $\mathrm{NaF}(0.01 \mathrm{M})$ & & 0.269 & 0.267 & 0.268 \\
\hline $\operatorname{EDTA}(0.01 \mathrm{M})$ & & 0.009 & 0.007 & 0.007 \\
\hline Nitrilotriacetic acid(NTA) $(0.01 \mathrm{M})$ & & 0.011 & 0.006 & 0.009 \\
\hline
\end{tabular}

* The $\mathrm{pH}$ of solutions are adjusted to 1.9 ,

The results in Table 1. show that ascorbic acid, tartaric acid and $\mathrm{NaF}$ solutions have no effect on the absorbance of [Bi(III)-AZIII ] complex , while other masking agents exhibit decreasing in the absorbance owing to their complexing action with bismuth. Therefore, composite mixture solution(II) is prepared by dissolving $0.8507 \mathrm{~g}$ of ascorbic acid (BDH) in 40 $\mathrm{mL}$ of composite mixture (I) and the volume is completed to $50 \mathrm{~mL}$ with distilled water in a volumetric flask and its effect on the absorbance of coloured complex is then examined
.The experimental results showed that $2 \mathrm{~mL}$ of the composite mixture solution(II) was optimum and it was recommended for the subsequent experiment. The order of addition on the absorbance is also investigated . The experiments showed that the order of $\left(\mathrm{Bi}(\mathrm{III})+\mathrm{HNO}_{3}+\right.$ composite mixture (II) + AZIII ) at $612 \mathrm{~nm}$ is the optimum because of its high absorbance value .

\section{Effect of surfactants}


The presence of surfactants in a coloured reaction mixture solution may frequently lead to an increase in the absorbance intensity and a shift in the wavelength to higher values. In this respect, sodium dodecyl sulphate (SDS) (anionic surfactant), cetyltrimethylammonium bromide (CTAB) and cetylpyridinium chloride (CPC) (cationic surfactants) and Triton X-100 (non-ionic surfactant) have been introduced. The results indicated that addition of surfactants show no useful effect. Therefore, they were omitted in this study.

\section{Effect of time on colour development}

To test the effect of time on the absorbance of the coloured complex at $612 \mathrm{~nm}$, the $\mathrm{Bi}(\mathrm{III})$ complex has been prepared from different amounts $(25$, 50 and $75 \mu \mathrm{g}$ ) of $\mathrm{Bi}(\mathrm{III})$ under the optimal experimental conditions, and the absorbance is measured at different time intervals up to $120 \mathrm{~min}$. Table. 2 indicats that the coloure of the complex develops immediately and the absorbance remains maximum and constant for at least 120 minutes.

Table (2). Effect of time on colour development of Bi(III) complex, ( AZIII : $5 \times 10^{-4} \mathrm{M}$; pH = 1.9 )

\begin{tabular}{|c|c|c|c|c|c|c|c|c|c|c|c|}
\hline \multirow{2}{*}{$\begin{array}{c}\boldsymbol{\mu g} \text { of } \\
\mathbf{B i}(\mathbf{I I I})\end{array}$} & \multicolumn{10}{|c|}{ Absorbance / min. } \\
\cline { 2 - 12 } & $\mathbf{I m m} *$ & $\mathbf{5}$ & $\mathbf{1 0}$ & $\mathbf{1 5}$ & $\mathbf{2 0}$ & $\mathbf{2 5}$ & $\mathbf{3 0}$ & $\mathbf{4 0}$ & $\mathbf{5 0}$ & $\mathbf{6 0}$ & $\mathbf{1 2 0}$ \\
\hline $\mathbf{2 5}$ & 0.133 & 0.133 & 0.132 & 0.133 & 0.132 & 0.132 & 0.131 & 0.131 & 0.130 & 0.131 & 0.129 \\
\hline $\mathbf{5 0}$ & 0.268 & 0.265 & 0.263 & 0.263 & 0.262 & 0.262 & 0.261 & 0.262 & 0.260 & 0.260 & 0.261 \\
\hline $\mathbf{7 5}$ & 0.323 & 0.324 & 0.321 & 0.321 & 0.321 & 0.320 & 0.320 & 0.318 & 0.318 & 0.318 & 0.316 \\
\hline
\end{tabular}

*Iimmediately : after dilution to the mark with distilled water using a $20 \mathrm{~mL}$ volumetric flask.

\section{Calibration curve}

Sandell's sensitivity have been found to be $1.9 \times 10^{4} \mathrm{~L}_{\mathrm{mol}}{ }^{-1} . \mathrm{cm}^{-1}$ and 0.0109 $\mu \mathrm{g} . \mathrm{cm}^{-2}$, respectively . The limit of detection (LOD) is $0.0633 \mu \mathrm{g} \cdot \mathrm{mL}^{-1}$ and the limit of quantification (LOQ) is $0.0847 \mu \mathrm{g} \cdot \mathrm{mL}^{-1}$.
A linear calibration curve passes through the origin is obtained over the concentration range of $2-85 \mu \mathrm{g}$ of $\mathrm{Bi}(\mathrm{III})$ in a final volume of $20 \mathrm{~mL}$ (i.e. $0.1 \quad-\quad 4.25 \mu \mathrm{g} \cdot \mathrm{mL}^{-1}$ ). Higher concentrations show a negative deviation from Beer's law (Fig.2). The apparent molar absorptivity and 


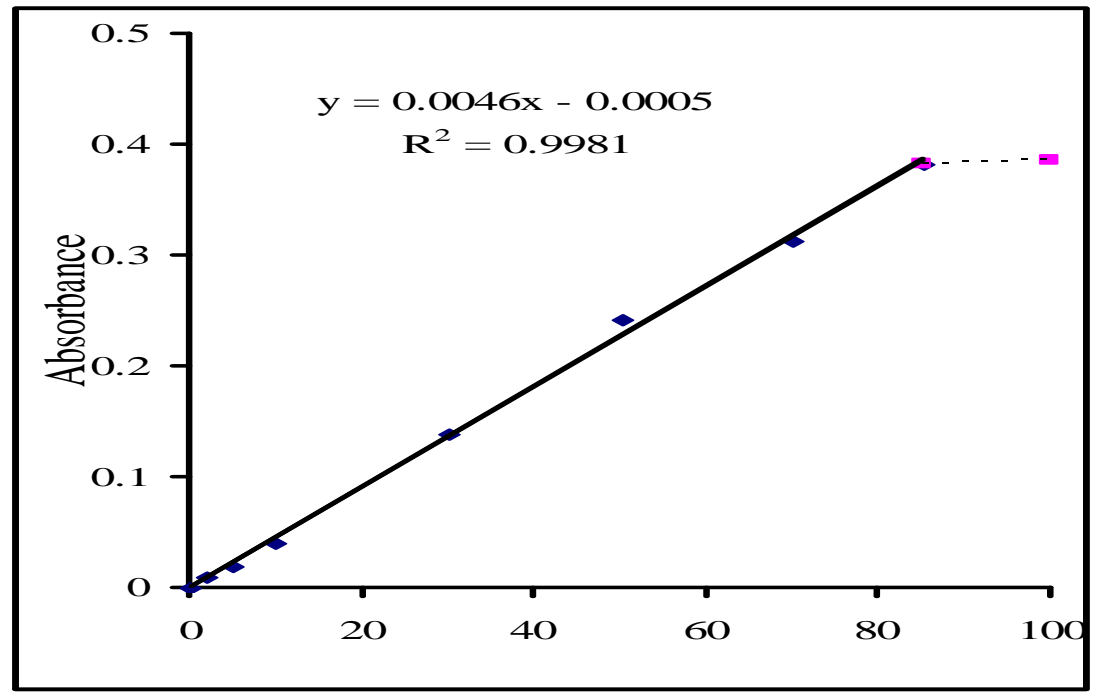

Conc. Bi $\mu \mathrm{g} / 20 \mathrm{~mL}$

Fig (2). Calibration curve for bismuth determination with $5 \times 10^{-4} \mathrm{M} A Z I I I$ reagent at pH1.9 and in the presence of $2 \mathrm{~mL}$ of composite mixture solution(II)

\section{Final absorption spectra}

solution(II) .The coloured complex exhibits maximum absorption at 612 $\mathrm{nm}$ against the reagent blank solution (Fig.3) .
Under the above established optimized conditions, bismuth ion forms a blue water soluble complex with AZIII reagent at $\mathrm{pH} 1.9$ in the presence of composite mixture

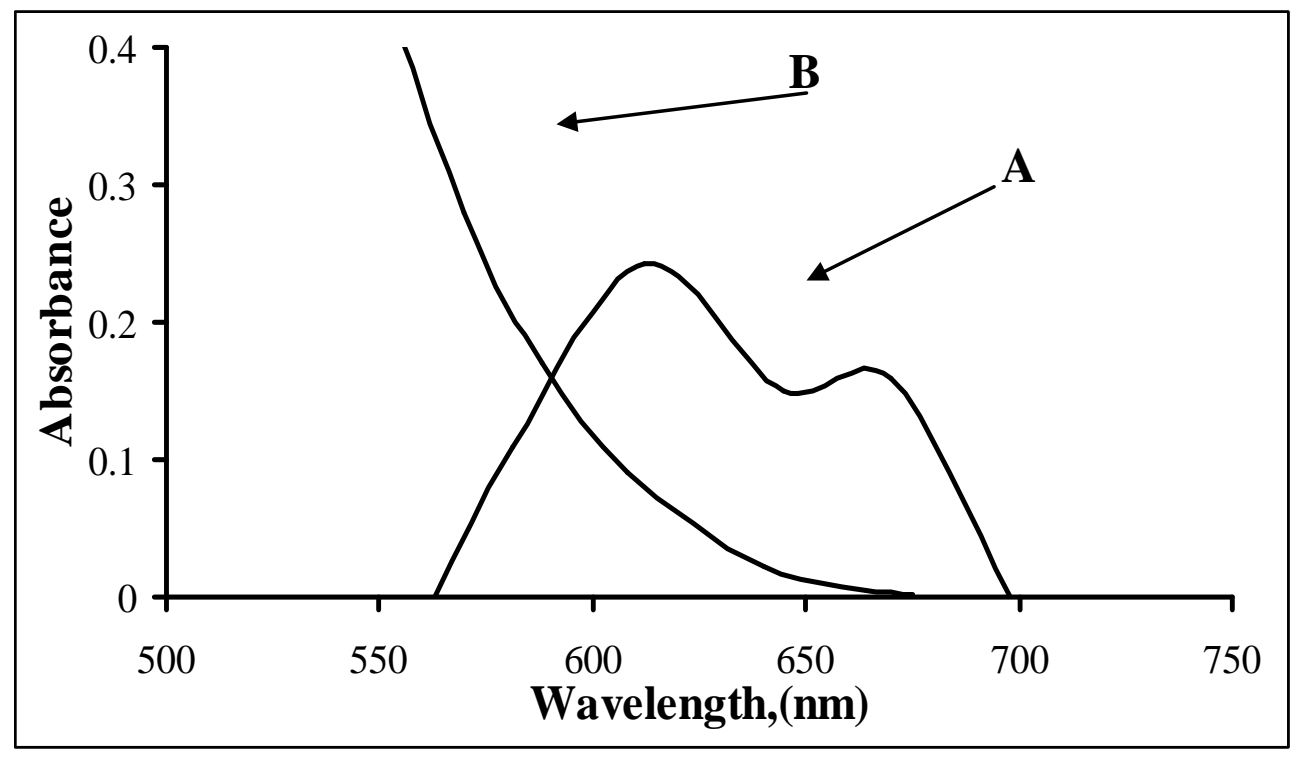

Fig (3). The absorption spectra (A) of $50 \mu \mathrm{g} B(\mathrm{III}) / 20 \mathrm{~mL}$ treated according to the recommended procedure $\left(1.5 \mathrm{~mL}\right.$ of $5 \times 10^{-4} \mathrm{M}$ AZIII and $3 \mathrm{~mL}$ of $0.1 \mathrm{M}$ $\mathrm{HNO}_{3}$ ) measured against blank and (B) blank against distilled water. 


\section{Composition of the complex}

The stoichiometry of the complex was studied under the established conditions by applying the continuous variation method (Job's method) and mole-ratio method [20]. The experiment results in both methods

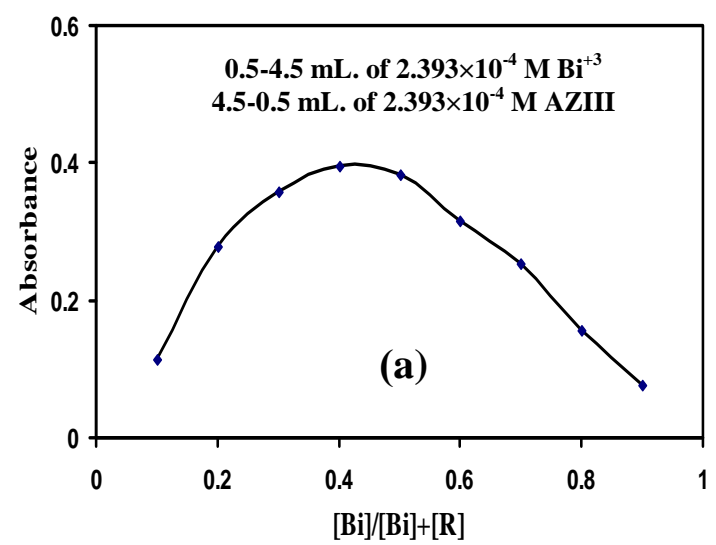

(Fig. 4) show that the molar ratio of Bi(III) to AZIII in the complex is found to be 1:2 . The stability constant of the coloured complex is also studied [21] and it was found to be $4.48 \times 10^{11} \mathrm{M}^{-2}$.

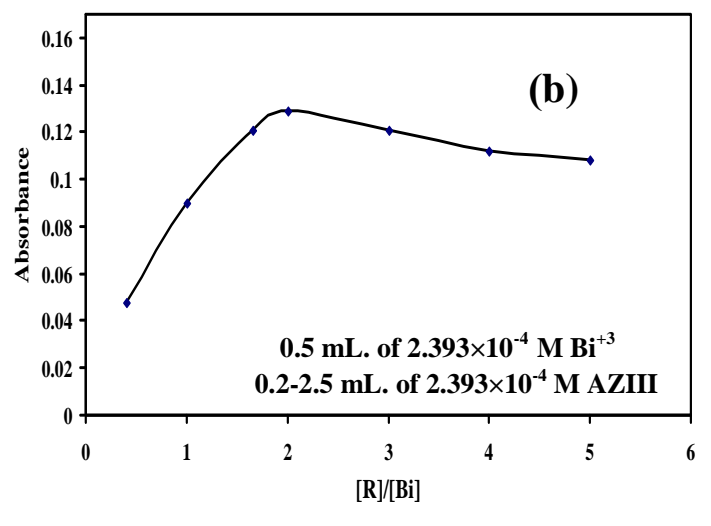

Fig (4) . (a) Continuous variation and (b) mole-ratio plots for Bi(III) - AZIII complex

\section{Effect of Interference}

tolerable. As shown in Table 3. The largest interfering species were found for $\mathrm{Al}^{3+}, \mathrm{Cu}^{2+}, \mathrm{Ni}^{2+}, \mathrm{Pb}^{2+}, \mathrm{Mn}^{2+}, \mathrm{Th}^{4+}$ and $\mathrm{PO}_{4}^{-3}$ ions .
Effect of interfering species on determination of $50 \mu \mathrm{g} / 20 \mathrm{~mL}$ bismuth was studied under optimum conditions with proposed method. An error of $\pm 5 \%$ in absorbance is considered

Table (3) . Individual tolerance limit of foreign ions on the determination of $\mathbf{5 0}$ $\mu \mathrm{g}$ of $\mathrm{Bi}$ (III)

\begin{tabular}{|l|l|}
\hline \multicolumn{1}{|c|}{ Foreign ions added } & Tolerance limit,$\mu \mathrm{g}$ \\
\hline $\mathrm{K}^{+}, \mathrm{Na}^{+}, \mathrm{Li}^{+}, \mathrm{Ag}^{+}, \mathrm{Fe}^{2+}, \mathrm{Br}^{-}, \mathrm{NO}_{3}^{-}$ & $2000-3000$ \\
$\mathrm{Hg}^{2+}, \mathrm{Mg}^{2+}, \mathrm{SO}_{4}^{2-}$ & 1000 \\
$\mathrm{SO}_{3}^{2-}, \mathrm{Cd}^{2+}, \mathrm{Ca}^{2+}, \mathrm{Ba}^{2+}, \mathrm{Zn}^{2+}, \mathrm{NH}_{4}^{+}$ & 500 \\
$\mathrm{Fe}^{3+}, \mathrm{Co}^{2+}, \mathrm{La}^{3+}, \mathrm{Cr}^{2+}$ & 250 \\
$\mathrm{Cu}^{2+}, \mathrm{Ni}^{2+}$ & 150 \\
$\mathrm{PO}_{4}^{-3}, \mathrm{~Pb}^{2+}, \mathrm{Mn}^{2+}$ & 50 \\
$\mathrm{Al}^{3+}, \mathrm{Cu}^{2+}$ & 25 \\
$\mathrm{Th}^{4+}$ & $<10$ \\
\hline
\end{tabular}

Also the effect of some foreign substances (e.g., glucose, lactose, starch and gum arabic), that usually present in dosage forms were studied by adding different amounts of foreign substances to $50 \mu \mathrm{g}$ of bismuth. It is observed that the studied foreign species did show any interfere with the proposed method (Table 4). 
Table (4) . Effect of additives and excipients on the determination of $50 \mu \mathrm{g}$ of Bi(III)

\begin{tabular}{|c|c|c|c|}
\hline Interferences & \multicolumn{3}{|c|}{ Recovery $(\%)$ of $50 \boldsymbol{\mu g} \mathbf{B i}(\mathbf{I I I}) / \boldsymbol{\mu g}$ of interferences } \\
\hline & $\mathbf{2 5 0}$ & $\mathbf{5 0 0}$ & $\mathbf{1 0 0 0}$ \\
\hline Glucose & 99.2 & 98.0 & 98.0 \\
\hline Lactose & 102.4 & 100.8 & 100.4 \\
\hline Starch & 100.0 & 100.4 & 101.6 \\
\hline Gum Arabic & 99.6 & 98.0 & 98.0 \\
\hline
\end{tabular}

Determination of $\mathrm{Bi}$ (III) in water samples

The proposed method has been successfully applied to the determination of bismuth(III) at three different concentrations added to appropriate volumes of tap , river and sea water samples. The results are compiled in Table 5 and showed that the proposed method is suitable for determining bismuth with satisfactory recovery.

Table (5) . Determination of Bi (III) in water samples

\begin{tabular}{|c|c|c|c|}
\hline Sample & ml. of sample & $\mathrm{Bi}(\mathrm{III})$ added, $(\mu \mathrm{g})$ & Recovery*, (\%) \\
\hline \multirow{9}{*}{ Tap water } & \multirow{3}{*}{2} & 25 & 98.3 \\
\hline & & 50 & 98.8 \\
\hline & & 75 & 100.8 \\
\hline & \multirow{3}{*}{5} & 25 & 96.7 \\
\hline & & 50 & 97.6 \\
\hline & & 75 & 99.2 \\
\hline & \multirow{3}{*}{10} & 25 & 97.5 \\
\hline & & 50 & 98.4 \\
\hline & & 75 & 101.8 \\
\hline \multirow{9}{*}{$\begin{array}{l}\text { River water } \\
\text { (Tigris river) }\end{array}$} & \multirow{3}{*}{2} & 25 & 101.6 \\
\hline & & 50 & 100.8 \\
\hline & & 75 & 100 \\
\hline & \multirow{3}{*}{5} & 25 & 100.8 \\
\hline & & 50 & 100.4 \\
\hline & & 75 & 99.5 \\
\hline & \multirow{3}{*}{10} & 25 & 99.2 \\
\hline & & 50 & 101.2 \\
\hline & & 75 & 100.8 \\
\hline \multirow{9}{*}{ Sea water** } & \multirow{3}{*}{2} & 25 & 98.2 \\
\hline & & 50 & 97.6 \\
\hline & & 75 & 98.4 \\
\hline & \multirow{3}{*}{5} & 25 & 88.4 \\
\hline & & 50 & 91.9 \\
\hline & & 75 & 94.0 \\
\hline & \multirow{3}{*}{10} & 25 & 85.7 \\
\hline & & 50 & 89.1 \\
\hline & & 75 & 91.4 \\
\hline
\end{tabular}

*average of three determinations

** Synthetic sea water was prepared according to the formula given in [22] 
Determination of $\mathrm{Bi}$ (III) in a Veterinary preparation:

The present method has been also applied to the determination of Bi (III) in veterinary preparation .The results are listed in Table 6 , from which it can be concluded that the method is suitable for determining bismuth in the veterinary preparation sample with satisfactory recovery.

Table (6) . Determination of Bi (III) in veterinary preparation

\begin{tabular}{|c|c|c|}
\hline Veterinary Preparation & Bi(III) amount $(\mu \mathrm{g})$ & Recovery, $(\%)^{*}$ \\
\hline \multirow{3}{*}{$\begin{array}{c}\text { Diaclean } 2000 \mathrm{mg} \\
\mathrm{Bi}_{5} \mathrm{O}(\mathrm{OH})_{9}\left(\mathrm{NO}_{3}\right)_{4} / \mathrm{Sachet} \\
\text { Avico, Jorden }\end{array}$} & 25 & 98.1 \\
\hline & 50 & 97.9 \\
\hline & 75 & 100.4 \\
\hline
\end{tabular}

*Average of five determinations.

The performance of the proposed method was assessed by calculating the student's t-test compared with the literature method [23]. The results in Table 7 show that the calculated values of $t$ do not exceed

the theoretical values at the $95 \%$ confidence level[24] indicating that there is no significant difference between the proposed method and the reported method.

Table (7) . Determination of bismuth by the proposed and literature methods

\begin{tabular}{|c|c|c|c|c|}
\hline \multirow[b]{2}{*}{ Veterinary Preparation } & \multirow{2}{*}{$\begin{array}{c}\text { Bismuth } \\
\text { amount, } \mu \mathrm{g}\end{array}$} & \multicolumn{2}{|c|}{ Recovery, \% ${ }^{*}$} & \multirow[b]{2}{*}{ t.exp** } \\
\hline & & $\begin{array}{l}\text { Present } \\
\text { method }\end{array}$ & $\begin{array}{c}\text { Reported } \\
\text { Method[24 ] }\end{array}$ & \\
\hline \multirow{3}{*}{$\begin{array}{c}\text { Diaclean } 2000 \mathrm{mg} \\
\mathrm{Bi}_{5} \mathrm{O}(\mathrm{OH})_{9}\left(\mathrm{NO}_{3}\right)_{4} / \text { Sachet } \\
\text { Avico, Jorden }\end{array}$} & 25 & 98.1 & 98.6 & 0.27 \\
\hline & 50 & 97.9 & 99.3 & 1.49 \\
\hline & 75 & 100.4 & 98.9 & 1.54 \\
\hline
\end{tabular}

*Average of five determinations.

**Tabulated $\mathrm{t}$-value at $95 \%$ confidence level is 2.31 for $(\mathrm{n}=10)$

\section{Conclusion:}

A simple, sensitive and accurate spectrophotometric method has been developed for determination of bismuth(III) in aqueous solution, using arsenazoIII (AZIII) as chelating agent at $\mathrm{pH} 1.9$. The molar absorptivity is $1.9 \times 10^{4} \mathrm{~L} \cdot \mathrm{mol}^{-1} \cdot \mathrm{cm}^{-1}$ at $612 \mathrm{~nm}$. Beer's law is obeyed over the concentration range $0.1-4.25 \mu \mathrm{g} \cdot \mathrm{mL}^{-1}$. The method has been applied successfully to the determination of $\mathrm{Bi}$ (III) in water samples and veterinary preparation .

\section{References:}

1. Gaikwad, S. H ; Mahamuni, S. V and Anuse, M. A. 2005. Extractive spectrophotometric determination of bismuth (III) in alloy sample using 1-amino-4, 4, 6-trimethyl $(1 \mathrm{H}, 4 \mathrm{H})$ pyrimidine-2-thiol, Indian J. Chem. Tech. 12: 365-368 .

2. Didi, M. A. ; Sekkal, A. R. and Villemine, D. 2011 . Cloud-point extraction of bismuth(III) with nonionic surfactants in aqueous solutions, Colloids and Surfaces A : Physicochem. Eng. Aspects 375 : 169-177.

3. Yang J. G. ; Yang, J. Y. ; Tang, M. T. ; Tang, C. B. and Liu, W. 2009. The solvent extraction separation of bismuth and molybdenum from a low grade bismuth glance flotation 
concentrate. Hydrometallurgy 96 : $342-348$.

4. Barakat, S. A. 2002. Flow injection extraction - spectrophotometric determination of bismuth with di(hydrogenated tallow alkyl) dimethylammonium chloride, Turk J. Chem. 26: 345-349 .

5. Yamini, Y. ; Chaloosi, M. and Ebrahimzadeh, H. 2002 . Solid phase extraction and furnace atomic absorption spectrometric determination of ultra trace amounts of bismuth in water samples , Talanta $56: 797-803$.

6. Chandrashekhar, P. M. and Mansing, A. A. 2008. Studies on liquid-liquid extraction and recovery of bismuth(III) from succinate media using 2octylaminopyridine in chloroform, J. Chin. Chem. Soc. 55: 807-817.

7. Afkhami, A.; Madrakian, T. and Siampour, H. 2006. Cloud point extraction spectrophotometric determination of trace quantites of bismuth in urine, J. Braz. Chem. Soc. 17(4): 797-802 .

8. Ling, M.A. ; Li-xin, Z. ; Ling-ling, F. and Wen-zhang, L. 2005. Determination of trace bismuth in geological samples by hydride generation-atomic fluorescence spectrometry, Rock and Mineral Analysis 24(3): 217-220 .

9. Araki, Y. ; Kagaya, S. ; Sakai, K. ; Matano, Y. ; Yamamoto, K. ; Okubo, T. and Tohda, K. 2008. Determination of $\mathrm{Al}, \mathrm{Cr}, \mathrm{Bi}, \mathrm{Fe}$, $\mathrm{Zn}, \mathrm{Cd}$ and $\mathrm{Pb}$ in crude drugs by inductively coupled plasma atomic emission spectrometry after coprecipitation with yttrium phosphate, J. of Health Science 54(6) : 682-685 .

10. Cui ,F. ; Wang, L. and Cui, Y. 2007 . Determination of bismuth in pharmaceutical products using methyltriphenylphosphonium bromide as a molecular probe by resonance light scattering technique
, J. Pharm. Biomed. Anal. 43(30) : 1033-1038 .

11. Kolpakova, N.A. and Glyzina, T.S. 2009 . Stripping voltammetric determination of bismuth in raw gold ores, J. Anal. Chem. 64( 12) : 1259-1263.

12. Hasdemir, E. and Karaboduk, K. 2010 . Simultaneous determination of bismuth and copper by square wave voltammetry in the presence of ethylenediaminetetraacetic acid, G.U. Journal of Science 23(1): 3339 .

13. Reddy , D.V. and Reddy, A.V. 2010 .Amperometric determination of bismuth using gallacetophenone phyenylhydrazone with the structureal elucidation of complex , E. J. Chem. 7(4) : 1290 - 1295 .

14. Jeronimo, P.C.A. ; Araujo, A.N. ; Montenegro, M.C.B. Santinsky, D. and Solich, P. 2004. Colorimetric bismuth determination in pharmaceutical using a xylenol orange sol-gel sensor coupled to a multicommutated flow system , Anal. Chem. Acta 504 : 235-241 .

15. Jan, K. ; Anna, A. ; Mariusz, S. and Wlodzimierz, R. 2007. Spectrophotometric determination of $\mathrm{Pb}$ (II), $\mathrm{Fe}$ (III) and $\mathrm{Bi}(\mathrm{III})$ in complexes with 1,2diaminocyclohexane $-\mathrm{N}, \mathrm{N}, \mathrm{N}, \mathrm{N}-$ tetraacetic acid (DACT), Polish. Pharm. Soc. 64(1): 3-8 .

16. Amin, A. S. 2011. Cloud-point extraction and spectrophotometric determination of trace quantites of bismuth in environmental water and biological sample, J. Spect. Lett. 44(6): 424-431.

17. Amir M. A. and Karel V. 2012.Determination of trace bismuth(III) by stripping voltammetry at antimony-coated carbon paste electrode, Int. J. Electrochem. Sci. 7: 68-76 .

18. Tzanavaras, P.D. ; Themelis, D.G. and Economou, A. 2004 . Sequential injection method for the direct spectrophotometric 
determination of bismuth in pharmaceutical products , Anal. Chem. Acta 505(7) : $167-171$.

19. Honova, D. ; Nemecove, I. and Suk, V. 1988 . Spectrophotometric determination of bismuth and EDTA by means of the reaction of bismuth with pyrocatechol violet in the presence of septonex , Talanta 35(10) : 803-804.

20. Delevic, R. 1997. Principles of quantitative chemical analysis, Mc. graw-Hill, Internatinonal Edn., Singapore, pp. 495-502 .

21. Hargis, L. G. 1988. Analytical chemistry, principles and techniques,

Prentice-Hall International, London, pp. 424-427.

22. Henriksen , A. .1965 . An automatic method for determining nitrate and nitrite in fresh and saline waters, Analyst $90: 83-88$.

23. Marczenko, z. and Balecrzak, M. 2004 . Separation, preconcentration and spectrophotometry in inorganic analysis, Elsevier, PP. 116-118 .

24. Christian, G. D. 2004. Analytical chemistry, John Wiley and Sons, $6^{\text {th }}$ Edn., Philadelphia, pp. 90-97.

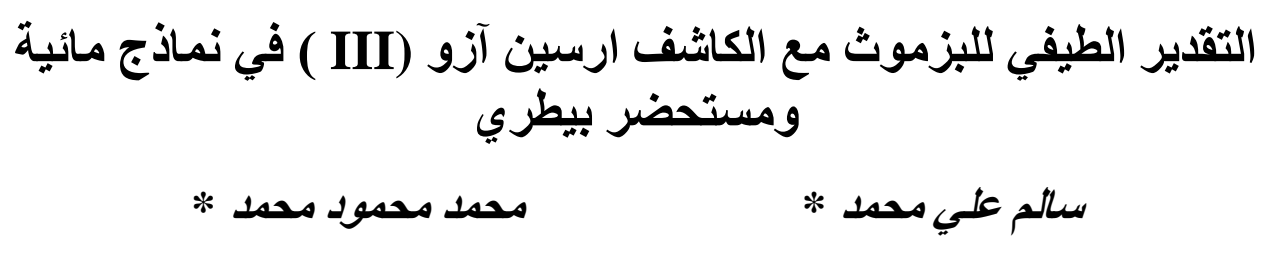

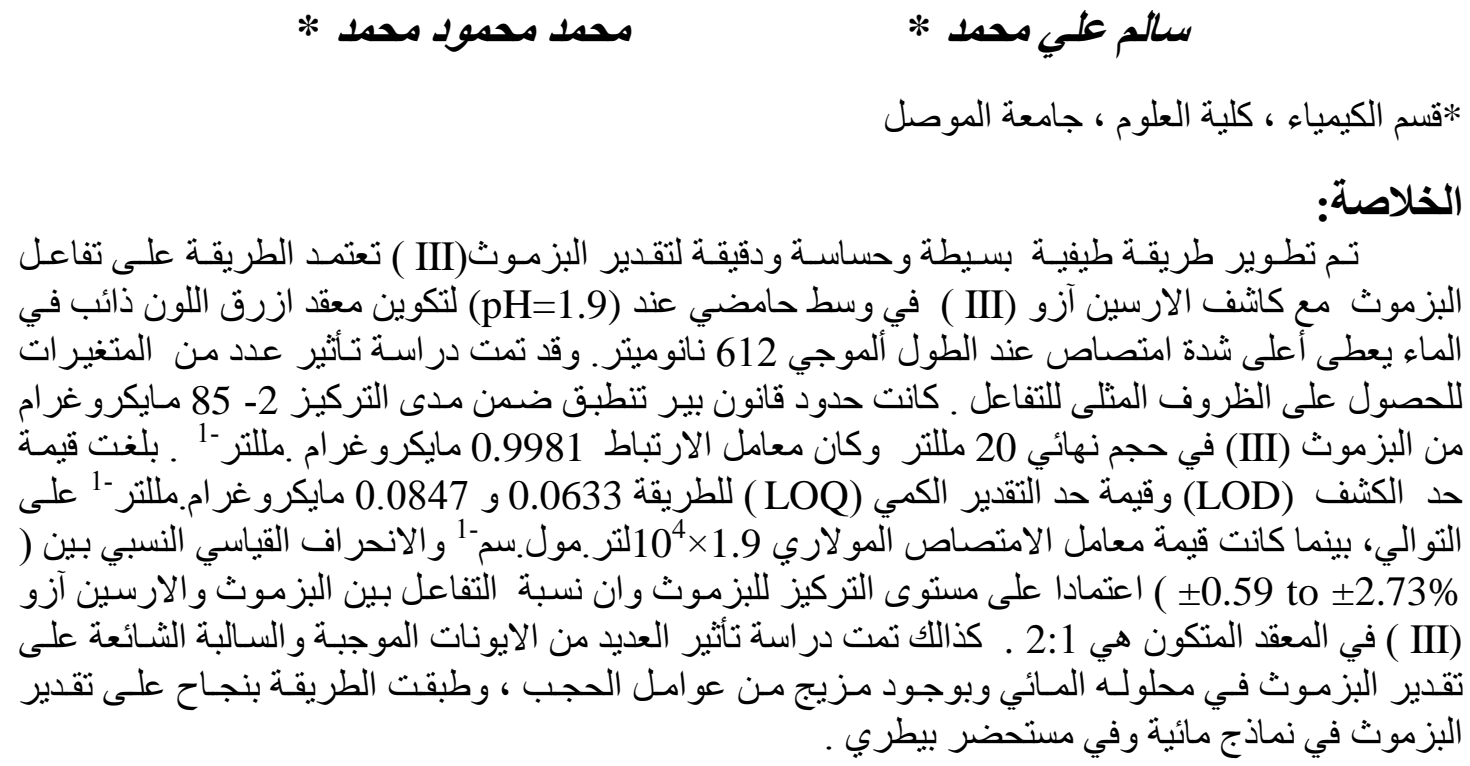

